\title{
Surviving and Thriving at a UK University through a Minority Lens
}

\author{
Gina Oswald \\ University of Maine at Farmington \\ Roxanne DuVivier \\ Samantha Wood \\ Tiffany Freeman \\ Wright State University
}

\begin{abstract}
Higher education institutions around the globe are focussed on creating inclusive environments for all students. Initiatives are being crafted to assist marginalised students to obtain better outcomes in key metrics such as enrolment rates, retention rates, graduation rates, and resultant employability statistics. This article presents findings from a quantitative study conducted at a large research university in the United Kingdom that examined factors that impacted the persistence and engagement levels of Black and Minority Ethnic students. The study examined such factors as resilience, challenges, persistence, decisionmaking, student support, communications and feelings of belonging. Significant differences were found among Black, Asian, White and Other minority groups on multiple factors contributing to persistence and engagement. Recommendations for practice change in university operations, specifically Student Affairs and Academic Affairs, are offered.
\end{abstract}

\section{Keywords}

minority students, higher education, BME students, engagement, persistence

\section{Introduction}

In recent years, colleges and universities in the United Kingdom (UK) have sharpened their focus on the success of underrepresented college student populations. As many institutions struggle with declining enrolment and retention rates, it has become critical to improve the university experience for the under-enrolled and under-retained populations, that have been historically underserved by the sector. One underrepresented group of particular importance to members of the higher education community comprises racial minorities. This category of populations in the UK is referred to as BME or "Black and Minority Ethnic... the terminology normally used in the UK to describe people of nonWhite descent" (Institute of Race Relations, 2020). In addition to identifying non-White students, BME is used to "describe patterns of marginalisation and segregation caused by attitudes toward an individual's ethnicity" (Ross et al., 2018). Although this term largely ignores identity intersectionality, it is widely known and used within the UK and Europe and will, therefore, be the terminology used to describe the population under investigation in this study.

\section{Participation and degree completion in higher education}

According to a study conducted by Smith (2017), in both the UK and the United States (US) BME students have lower rates of participation, completion, engagement, belonging, and persistence when compared to their white peers. These conditions result in a concerning attainment gap that must be addressed by institutions of higher education. On a positive note, enrolments of BME students have markedly increased within the UK higher education sector in recent years. In a 4-year timeframe between the 2014/15 and 2018/19 academic years, universities in the UK experienced an 18\% increase of non-White students (HESA, n.d.). According to the Higher Education Statistics Agency (HESA, n.d.), 2,383,970 students were enrolled for the 2018/2019 academic year in the UK. Of that number, $76 \%$ of students identified as White while the other $24 \%$ of students identified as Black (7\%), Asian (11\%), Mixed (4\%), or Other (2\%). These statistics from HESA can be compared to the racial demographic statistics for the UK as a whole, which show that almost $88 \%$ of British citizens 
are White, roughly 3\% are Black, and the other $9 \%$ of the population are Asian, Mixed, or Other (Index Mundi, 2019). These data demonstrate that BME students are represented in higher education in numbers that exceed their average representation in the UK population, while White students attend at a lower rate than would be expected based on the population.

However, irrespective of this increase, student success outcomes for BME students in the form of retention and degree attainment are not rising commensurate with the increase. According to HESA, domestic BME students are less likely to receive first or upper second-class degrees when compared to their White counterparts, or they are also less likely to persist altogether to degree completion (Ross et al., 2018; The National Archives, 2015). First or upper second-class degrees refer to the two highest degree markers within the UK's higher education classification system (Universities and Colleges Admissions Service, 2020). So, white students are more likely to graduate with higher honours than their BME counterparts. The English Higher Education Funding Council assembled student characteristics of over 200,000 graduates in 2013-2014 and also found that $76 \%$ of White students obtained an upper-class degree, while only $60 \%$ of BME students obtained an upper-class degree. This trend held true even when other characteristics such as socio-economic status, cultural backgrounds, entry qualifications, and family commitment were controlled (Ross et al., 2018).

Academics posit that there are many reasons for this disparity, including several generations of inequality and institutionalised racism, and that addressing these inequities requires a firm understanding of current underlying causes. A recent article by Cotton (2013) argued that active participation is lower among BME students when compared to white students due to a severe lack of representation in faculty, staff, and students. Applying Tinto's theory of retention, Cotton (2013) claimed that BME students have less contact with their peers, staff, and faculty because they do not see themselves represented among the ranks. This results in BME students being less socially and academically engaged across institutional offerings. In this article, social engagement was defined as engagement with non-academic, extra-curricular activities such as student organisations, while academic engagement was defined as engagement within the classroom and with the faculty members. This issue is heightened at predominantly-white institutions, where BME students are more likely to feel isolated, or where their experiences are muted (Harmon, 2009). It is noteworthy to add that female students as a demographic show higher participation rates when compared to their male peers, even within the BME community, for undetermined reasons (Cotton et al., 2015).

Beyond the UK, a study completed by Stevenson and Whelan (2013) focussed on the attainment gap between Black and White students and how that gap affects the completion rates for Black students across the US. This study examined financial aid records and concluded that the majority of Black and Latinx students come from low-income families and rely on financial aid funds to attend college. Financial aid opens doors for American BME students because, without funding, many BME students would not have the same opportunities to attend university as their white counterparts. This also means that if students lose funding, they may lose the ability to persist altogether. Many Black and Latinx students also come into college with additional family and personal life challenges, like supporting single parents or siblings, children of their own, or managing full -time employment responsibilities in addition to their studies. These challenges can negatively impact American BME students' ability to persist and engage with their college community. Their families and personal lives, of necessity, take priority over academic commitments (Stevenson \& Whelan, 2013). These factors may also be useful in the examination of lower BME completion rates within UK universities and may have relevance in examining BME student engagement and persistence.

\section{Student engagement}

Traditionally, being involved in campus life and activities can make a significant positive difference in a student's academic life. Oftentimes students with higher rates of belongingness and feelings of acceptance on campus also have higher grades, are more likely to persist and graduate, and are happier overall with their college experiences (Shoderu et al., 2012). A study conducted across three 
universities in the UK focussed on these phenomena to gauge student engagement and belongingness. Here, focus groups were conducted with students from gender and ethnically diverse backgrounds at London Metropolitan University, Anglia Ruskin University, and the University of Westminster. Participants were given Biographic Narrative Interpretative Method (BNIM) interviews, where they were asked to recount specific examples of engagement and feelings of belongingness on campus (Shoderu et al., 2012). Three main groups of students were represented in these focus groups: White students who were born and educated in the UK, students who were born in Africa but educated in the UK, and students who were born and educated in South America (mostly Brazil). The emergent theme from the group of Brazilian students was that they felt isolated due to significant differences in their culture versus the predominant UK culture (Shoderu et al., 2012). Many of the students remarked that Brazilian culture is emotionally warmer and more familial, whereas, to them, English culture seemed colder and less friendly. This cultural difference caused them to feel isolated to a point where they only affiliated with other students from South America, rather than with students in the college population as a whole. The African students came to similar conclusions, noting that the majority social groups (particularly comprising white students) felt impenetrable (Shoderu et al., 2012). The perception that these groups of college students were socially exclusionary made the African students feel even more isolated. Interestingly, when asked about socialising with BME students, the White students in the study mentioned experiencing a very similar "exclusionary" phenomenon. They indicated that they felt as though the BME and international students stuck together in tight-knit groups, which felt impenetrable to White students (Shoderu et al., 2012). A perceived sense of group boundaries/exclusivity appears to be perpetuating a social chasm between these ethnically diverse groups.

In addition to social engagement, supporting and academically engaging BME students is of importance to ensure that students receive the necessary tools and resources to engage and persist throughout their college careers. Worrall-Hill (2014) conducted a study to measure the importance of support for BME students by creating and measuring the results of a mentoring program at Staffordshire University in the UK. In this program, BME students were paired with other BME students based on commonality of department, major, and interests. The mentoring initiative allowed new BME students to pair with third or fourth year BME students to help guide them through university life and connect new students to resources. This intervention was not only meant to provide students with a personal connection with the campus, but also to teach BME students valuable skills such as networking, business etiquette, guidance on how higher education works, coupled with helpful reflective practices such as self-evaluation of learning. According to testimonials from participants in the study, the Staffordshire mentoring initiative was deemed impactful. Participating students reported feeling more prepared for their degrees, understood more about higher education, could more easily approach their professors with questions, and were more likely to persist through university (Worrall-Hill, 2014).

\section{Student persistence}

BME student persistence from the point of deciding to enter higher education through to degree completion is yet another area of concern for university leadership. Beginning before a student enrols in a degree program, research indicates that BME students face more challenges during the initial application process to higher education than their white counterparts (Bhopal, 2017). Evidence suggested that BME students continue to experience discrimination, and feel rejected in higher education, especially at the elite, Russell Group universities. According to a study conducted by Boliver (2016), ethnically diverse students are less likely to receive offers of admission to Russell Group colleges and universities than similarly qualified white candidates. Sadly, these negative views appear to be similarly held by minority students in both the UK and US higher education systems (Bhopal, 2017). 
Another success challenge is entwined with the relationship minority students have with staff and faculty on university campuses. There is a need for higher education institutions to intentionally create spaces for minority students as well as compel instructors to incorporate more culturally diverse views into the curriculum, thereby promoting equity within the curriculum (Sanders \& RoseAdams, 2014). More positive interpersonal interactions can increase persistence and a sense of belongingness for minority students on campus, thus the importance of students' relationships with faculty must be reinforced (Kim \& Lundberg, 2015). Though the importance of relationships is applicable for all students, one study noted that it is even more relevant for minority students, who often have fewer interactions with, and access to, faculty, and are therefore disadvantaged in the classroom (Kim \& Lundberg, 2015). It follows that there is not only need for institutional policy change, but there is also a clear need for curriculum change to embed diversity and inclusion, and decolonisation into the curriculum. Having diverse representation within faculty and staff can also help to diversify the campus and build better relationships with BME students. If BME students see themselves represented within the staff and faculty, they are more likely to reach out or look up to minoritised staff as role models, which can have a positive impact on their learning environments (Collins \& Kritsonis, 2006).

Additionally, there is a difference in the way BME students feel when it comes to their sense of being valued in higher education in the UK compared to their White peers. The approach toward success in UK higher education institutions creates challenges for many BME students and has led to an exodus of BME students to overseas academic institutions that provide the nurturing environment BME students need to succeed in higher education (Bhopal, 2017). These BME students reported that during their UK higher education journey, they faced specific challenges in regard to the time and degree progression. This research indicated that BME students believed they were required to work twice as hard as others from the predominant ethnic group, in order to be successful. This perception is supported by other studies that have shown that BME students were held to a higher standard of performance, such as being required to complete a higher number of academic publications in comparison to their non-BME peers (Bhopal, 2017). It can be surmised that such disparate treatment, coupled with other hurdles, such as life circumstances, financial stress, the need to work, and high expectations, have made attaining success more difficult for BME students in the UK. Finding solutions is complicated by the fact that conditions that give rise to the problem are oftentimes unintentional, 'very, very subtle racism' and 'unconscious bias' (Bhopal, 2017). This institutionalised discrimination can lead to lower levels of social capital and self-esteem, which in turn can affect not only BME students' studies but also their feelings of value on campus (Singh, 2009). Singh (2009), therefore, argues that whether or not the bias is intentional, institutional racism must be challenged in higher education to provide better opportunities for BME student success.

One documented cause of the difference in standards between BME students and their peers is the overrepresentation of one ethnic group over another in a specific academic department (Walker, 2010). BME students have often been members of a small minority, if not the only minority, in their chosen department. The inequities within sections of academia may create for BME students an exclusionary feeling of unfair proportioning of workload along with differential expectations when compared to their white counterparts. Additionally, there has been a decrease in the ability of BME students to enter into institutions other than those located in urban settings. This de facto exclusion of BME students is seen markedly within Russell Group universities and, as Boliver (2016) argued, results in the formation of 'Black ghettos' in the institutional circuit (Walker, 2010).

Due to perceived exclusionary practices, a growing number of BME students are relocating overseas (Walker, 2010). BME students express increased interest in the career advancement opportunities that certain countries, like the US, provide to accelerate their careers (Walker, 2010). The increased desire for race and ethnicity studies has drawn many BME students to countries that consider these programs to be 'credible' disciplines and this interest has led to more in-depth Ethnic Studies 
coursework being developed (Walker, 2010). Additionally, the previously mentioned lack of representation of BME individuals in faculty and staff positions serves to exacerbate the exodus of BME students from higher education in the UK. In recent years, the UK has placed more focus on fostering academic practices centred around BME students that include formal and informal mentorship opportunities within and outside of the institution (Worrall-Hill, 2014). In recognising both the market value of diversity and its inherent social value, UK institutions can engage and retain BME staff and students and promote healthy, sustainable programs for diversified ethnic groups of individuals in higher education (Worrall-Hill, 2014).

According to Morales (2008), resilience is a skill all students in higher education need to learn and apply to achieve academic success and overall personal wellbeing. As it relates to thriving in higher education as a minority student, research suggests that the university environment negatively impacts the development of resiliency skills. The higher education environment that minority students are entering is based on predominantly White middle and upper- class norms and values. These environmental and cultural factors create sizable hurdles for BME students and generate a greater need to practice resiliency. This is particularly true at institutions that have roots in catering predominately to students from a White culture. Thus, for BME students, the move to university is often a difficult transition that requires assimilation rather than identity expression (Morales, 2008). Morales (2008) described the pressures BME students faced related to constant cultural discontinuity, along with the tension that arises from perpetually accommodating to a culturally different environment. The "constant discontinuity, whether obvious or subtle, creates stressful experiences for individuals from BME backgrounds during the resilience development process" (Morales, 2008, p.159). Ross and colleagues (2018) argued that this discontinuity can be curbed through active, intentional interventions by faculty and staff via activities such as bias-training or equity education. Institutions must advocate for BME students through social justice education and inclusive practices in a conscious effort to raise resilience and persistence rates (Ross et al., 2018). Given the additional difficulties faced by minoritised students, becoming resilient in higher education is necessary for better academic and career outcomes and is critical for minority students if they are to survive and thrive in an inherently discriminatory and racist system (Morales, 2008).

In order to further the critical discussion of factors related to student success and experience in higher education in the UK, a secondary analysis of an original study by DuVivier and colleagues (2018) was conducted to recognise and investigate possible differences between student groups based on race/ethnicity. Specifically, the study was designed to further clarify student perceptions around factors related to academic engagement, co-curricular support, student decision-making, students' sense of belonging and student resiliency, all factors previously associated with student persistence and engagement. The researchers sought to answer the following research questions:

1. What engagement factors were associated with BME university students in the UK context?

2. What persistence factors were associated with BME university students in the UK context?

3. Is there a difference between BME students and non-BME students' levels of engagement and persistence factors in a UK context?

Ultimately, understanding BME student experiences and perceptions of factors related to student success in UK universities can generate more targeted services and interventions to support student retention, foster higher levels of student engagement and improve student success.

\section{Methodology}

For this study, the researchers conducted a secondary analysis to the original study completed in 2017 (DuVivier et al., 2018). Secondary analyses provide researchers with an opportunity to examine new 
research questions through previously established datasets that are often inclusive of underrepresented groups (Little, 2013). Quantitative questions contained in the original sample were analysed through a race/ethnicity lens.

\section{Participants}

A total of 226 university students agreed to complete at least part of the survey. For the purposes of this study, both the broad category of BME was utilised to compare to non-BME/White participants, as well as the further refined categories of Black and Asian as the two largest BME categories in the UK. Any participant who identified as Asian, Indian, Pakistani, Bangladeshi, Hindu, Chinese, Sri Lankan, or Filipino was considered Asian for this study. As well, anyone who identified as Black, Black British, African, Black African, Black Caribbean, Black Swedish, Black Italian, Nigerian, was considered Black for the purposes of this study. Any person who did not fit into either the Asian or Black category as defined above but did fit into the BME category was considered BME and placed in the Other category when race/ethnicities were further refined. For example, a person who reported a mixed ethnicity would be considered BME and Other. There were 49 individuals who did not provide information necessary to determine BME status and were therefore excluded from the study, leaving 177 participants for this secondary analysis. Participants were also asked to specify their gender, which campus they attended, and various demographics such as traditional, international, and commuting which further aided identification of student cohorts. Demographics are provided in Table 1. Respondents of the survey appear to be similarly representative of this university's demographics based on a snapshot of student demographic data from December 2017. According to this snapshot, the university has $61 \%$ White students, almost $11 \%$ Black students, $12 \%$ Asian students, while the other $16 \%$ of students were mixed, other, unknown, or preferred not to say (Anglia Ruskin University Student Snapshot, 2017).

Table 1

Frequency (and percentage) demographics of study participants by race/ethnicity

\begin{tabular}{|l|l|l|l|l|}
\hline Student Category & \multicolumn{1}{|c|}{ Asian } & \multicolumn{1}{c|}{ Black } & \multicolumn{1}{c|}{ BME } & White \\
\hline Race/Ethnicity & $30(13.3)$ & $24(10.6)$ & $65(28.8)$ & $112(49.6)$ \\
\hline Female & $23(76.7)$ & $17(70.8)$ & $45(69.2)$ & $65(58.0)$ \\
\hline Male & $7(23.3)$ & $6(25.0)$ & $19(29.2)$ & $44(39.3)$ \\
\hline No reported gender/Other & $0(0.0)$ & $1(4.2)$ & $1(1.5)$ & $3(2.7)$ \\
\hline Metropolitan Campus & $17(56.7)$ & $15(62.5)$ & $34(61.5)$ & $68(61.3)$ \\
\hline Suburban Campus & $13(43.3)$ & $9(37.5)$ & $31(47.7)$ & $43(38.7)$ \\
\hline Traditional & $6(20.0)$ & $7(29.2)$ & $18(27.7)$ & $40(35.7)$ \\
\hline Mature & $5(16.7)$ & $7(29.2)$ & $15(23.1)$ & $36(32.1)$ \\
\hline Commuting & $7(23.3)$ & $4(16.7)$ & $11(16.9)$ & $34(30.4)$ \\
\hline Clearing & $0(0.0)$ & $1(4.2)$ & $1(1.5)$ & $9(8.0)$ \\
\hline First Generation & $7(23.3)$ & $0(0.0)$ & $7(10.8)$ & $21(18.8)$ \\
\hline $\begin{array}{l}\text { Students with Caring } \\
\text { Responsibilities }\end{array}$ & $3(10.0)$ & $1(4.2)$ & $4(6.2)$ & $11(9.9)$ \\
\hline International & $11(36.7)$ & $10(41.7)$ & $28(43.1)$ & $7(6.3)$ \\
\hline
\end{tabular}

\section{Instrumentation}

For the original study (DuVivier et al., 2018), a multi-factor student retention and engagement survey was designed to explore factors influencing student retention and student engagement. The instrument was piloted, revised, and reviewed by the UK university's student engagement office before use in this study. The final survey included 26 close-ended quantitative items related to surviving and thriving at the university. 


\section{Data analysis}

All quantitative data were analysed using SPSS (version 26) for Mac. Descriptive statistics, frequency distributions, and Mann-Whitney U analyses were used to examine the research questions. The MannWhitney $U$ test was utilised to assess potential differences between BME and non-BME participants. This test was selected based on the ordinal nature of the dependent variable (Likert-type item responses) and because the data met all required assumptions.

\section{Limitations}

The open-ended nature of the ethnicity question required researcher judgment on category placement in some instances. Research judgment was based on a panel of researchers determining if ethnicity could be determined and which British-recognised ethnicity category each participant fell into. When ethnicity was not clear, the participant was not included in the study. Future research should provide a set of standard ethnicity groupings from which participants can choose for consistency. Many countries utilise a specific ethnicity category scheme that can be employed for these purposes (e.g. British ethnicity classifications ["Ethnicity Facts and Figures", n.d.]). In addition, although the MannWhitney $U$ test is one of the most powerful non-parametric tests available (Landers, 1981), the study should be replicated to increase the sample size and ensure reliability of the results across groups and institutions.

\section{Results}

\section{Engagement factors}

Participant perceptions on feelings of belonging to the university were explored through multiple questions. When asked which statement was the best fit for them, 34 (52.3\%) BME participants reported feeling valued at the university by faculty, staff and fellow students; $25(38.5 \%)$ reported feeling valued at the university only by some of the university community, $3(4.6 \%)$ reported no sense of being valued, and 3 students $(4.6 \%)$ made no response to that question. These results suggest slightly higher rates of feeling valued compared with non-BME participants, as $50 \%$ felt valued, $36 \%$ felt somewhat valued, $11.6 \%$ did not feel valued, and $2.7 \%$ did not respond. There were six additional Likert-type item questions ( $\mathrm{A}=$ always, $\mathrm{S}=$ sometimes, $\mathrm{N}=$ never) on belonging, with results of those BME participants who responded reported in Table 2.

\section{Table 2}

Percentages for questions related to belonging by racelethnicity

\begin{tabular}{|c|c|c|c|c|c|c|c|c|c|}
\hline \multirow{2}{*}{$\begin{array}{l}\text { Student Category } \\
\text { Question }\end{array}$} & \multicolumn{3}{|c|}{ Asian } & \multicolumn{3}{|c|}{ Black } & \multicolumn{3}{|c|}{ White } \\
\hline & Always & $\begin{array}{l}\text { Some } \\
\text { times }\end{array}$ & Never & Always & $\begin{array}{l}\text { Some } \\
\text { times }\end{array}$ & Never & Always & $\begin{array}{l}\text { Some } \\
\text { times }\end{array}$ & Never \\
\hline Easy to Become Part of Campus Life & 50.0 & 50.0 & 0.0 & 37.5 & 58.3 & 4.2 & 32.7 & 62.7 & 4.5 \\
\hline Belong on University's Campus & 62.1 & 34.5 & 3.4 & 54.2 & 41.7 & 4.2 & 52.3 & 42.2 & 5.5 \\
\hline $\begin{array}{l}\text { Social Media Connects to People on } \\
\text { Campus }\end{array}$ & 50.0 & 36.7 & 13.3 & 37.5 & 37.5 & 25.0 & 30.3 & 49.5 & 20.2 \\
\hline $\begin{array}{l}\text { Broader Community Outside of } \\
\text { University }\end{array}$ & 36.7 & 50.0 & 13.3 & 21.7 & 47.8 & 30.4 & 15.9 & 53.3 & 30.8 \\
\hline Make Friends in my Classes & 73.3 & 26.7 & 0.0 & 37.5 & 58.3 & 4.2 & 62.6 & 34.6 & 2.8 \\
\hline $\begin{array}{l}\text { Make Friends Outside Class at } \\
\text { University }\end{array}$ & 53.3 & 36.7 & 10.0 & 33.3 & 54.2 & 12.5 & 27.5 & 49.5 & 22.9 \\
\hline
\end{tabular}


Participants were also asked about their interactions with student support services. When asked whether they used campus resources when they needed them, 28 (43\%) BME participants reported 'always', 36 (55\%) replied 'sometimes', and 1 (1.5\%) indicated 'never'. These findings are relatively comparable to non-BME participants as $48.2 \%$ responded 'always', $51.2 \%$ 'sometimes', and $0 \%$ for 'never'. Results also indicated that 18 students 'always' (28\%) felt known and supported by student services staff another 39 students indicated they 'sometimes' (60\%) felt known and supported by student services staff, and 6 students indicated that they 'never' (9\%) felt known and supported by student services staff. Only 2 students (3\%) did not respond to the question. Similarly, 30.4\% of nonBME participants reported 'always', while $45.5 \%$ reported 'sometimes', $19.6 \%$ reported 'never', and $4.5 \%$ did not respond. The respondents' preferred and actual communication methods for contacting student services staff were explored and are reported by percentage in Table 3. Only 18 (27.7\%) stated they were very active and engaged in student life activities, whereas 35 (53.8\%) indicated they were active sometimes, $11(16.9 \%)$ were never active and engaged in student life activities, and one individual $(1.5 \%)$ did not respond. In contrast, non-BME were less engaged with $18.8 \%$ reporting being very active, $42.9 \%$ sometimes active, $34.8 \%$ never active, and $3.6 \%$ not responding.

Table 3

Percentage preferred and actual communication methods for student services by racelethnicity

\begin{tabular}{|c|c|c|c|c|c|c|c|c|}
\hline \multirow{2}{*}{$\begin{array}{l}\text { Student Category } \\
\text { Method }\end{array}$} & \multicolumn{2}{|c|}{ Asian } & \multicolumn{2}{|c|}{ Black } & \multicolumn{2}{|c|}{ BME } & \multicolumn{2}{|c|}{ White } \\
\hline & Preferred & Actual & Preferred & Actual & Preferred & Actual & Preferred & Actual \\
\hline Email & 56.7 & 60.0 & 37.5 & 45.8 & 44.6 & 50.8 & 50.0 & 47.3 \\
\hline Telephone & 10.0 & 10.0 & 20.8 & 8.3 & 15.4 & 9.2 & 5.4 & 4.5 \\
\hline Social Media & 10.0 & 3.3 & 0.0 & 8.3 & 4.6 & 4.6 & 2.7 & 0.9 \\
\hline Coming to Office & 26.7 & 20.0 & 50.0 & 50.0 & 40.0 & 38.5 & 24.1 & 18.8 \\
\hline More than One & 0.0 & 0.0 & 4.2 & 4.2 & 3.1 & 1.5 & 6.3 & 4.5 \\
\hline $\begin{array}{l}\text { Do not } \\
\text { Communicate }\end{array}$ & 16.7 & 16.7 & 8.3 & 12.5 & 10.8 & 12.3 & 25.9 & 31.3 \\
\hline
\end{tabular}

Academic engagement was the third area of consideration. Of those who responded to the question, $37(56.9 \%)$ BME participants reported that professors 'always' helped them succeed in class, while $22(33.8 \%)$ noted help was obtained 'sometimes', $4(6.2 \%)$ reported 'never' receiving help, and 2 individuals $(3.1 \%)$ did not respond. These results can be compared to non-BME participants, as $47.3 \%$ reported 'always', $46.4 \%$ 'sometimes', and 2.3\% never. When asked about engagement, 24 $(36.9 \%)$ participants stated they were very active and engaged in academic activities, while 32 (49.2\%) reported being sometimes active and engaged, $8(12.3 \%)$ reported they were 'never' active and engaged in academic activities, and one (1.5\%) did not respond. Slightly lower, $27.7 \%$ of nonBME participants were very active, $50 \%$ were sometimes active, and $18.8 \%$ were never active.

Respondents' preferred, and actual, communication methods for contacting professors were explored and are reported in Table 4, illustrating a clear difference between preferred and actual communication styles. Participants were also asked about what matters in the classroom and how they typically felt when in the classroom. Differences between student categories are presented and outlined in Table 5. 
Table 4

Percentage preferred and actual communication methods for professors by racelethnicity

\begin{tabular}{|c|c|c|c|c|c|c|c|c|}
\hline \multirow{2}{*}{$\begin{array}{l}\text { Student Category } \\
\text { Method }\end{array}$} & \multicolumn{2}{|c|}{ Asian Students } & \multicolumn{2}{|c|}{ Black Students } & \multicolumn{2}{|c|}{ BME } & \multicolumn{2}{|c|}{ White Students } \\
\hline & Preferred & Actual & Preferred & Actual & Preferred & Actual & Preferred & Actual \\
\hline Email & 93.3 & 86.7 & 83.3 & 85.7 & 86.2 & 84.6 & 85.7 & 82.1 \\
\hline Telephone & 6.7 & 6.7 & 8.3 & 0.9 & 7.7 & 7.7 & 0.9 & 0.9 \\
\hline $\begin{array}{l}\text { Coming to Office or } \\
\text { Office Hours }\end{array}$ & 23.3 & 10.0 & 29.2 & 15.2 & 23.1 & 12.3 & 15.2 & 12.5 \\
\hline Before/After Class & 20.0 & 16.7 & 16.7 & 19.6 & 18.5 & 29.2 & 19.6 & 17.0 \\
\hline More than One & 6.7 & 3.3 & 8.3 & 16.1 & 10.8 & 6.2 & 16.1 & 15.2 \\
\hline $\begin{array}{l}\text { Do not } \\
\text { Communicate }\end{array}$ & 0.0 & 3.3 & 0.0 & 1.8 & 0.0 & 1.5 & 1.8 & 2.7 \\
\hline
\end{tabular}

Table 5

Percentages of study participants' perceptions by racelethnicity

\begin{tabular}{|c|c|c|c|c|}
\hline & Asian & Black & BME & White \\
\hline \multicolumn{5}{|c|}{ What matters in the classroom: } \\
\hline Faculty Expertise & 26.7 & 25.0 & 27.7 & 38.4 \\
\hline Faculty Enthusiasm & 60.0 & 37.5 & 50.8 & 66.1 \\
\hline Course Content & 40.0 & 50.0 & 46.2 & 52.7 \\
\hline Student Rapport & 16.7 & 8.3 & 10.8 & 24.1 \\
\hline \multicolumn{5}{|c|}{ In class I typically feel: } \\
\hline Confident & 43.3 & 16.7 & 35.4 & 44.6 \\
\hline Hesitant & 10.0 & 20.8 & 13.8 & 21.4 \\
\hline Accepted & 33.3 & 33.3 & 33.8 & 41.1 \\
\hline Indifferent & 6.7 & 12.5 & 9.2 & 17.0 \\
\hline Interested & 36.7 & 45.8 & 43.1 & 55.4 \\
\hline Bored & 13.3 & 25.0 & 20.0 & 17.9 \\
\hline
\end{tabular}

\section{Persistence factors}

Factors related to participant decision making were assessed through various questions. The initial choice of university and later choice to remain at the university were explored and are reported in Table 6. BME participants also reported on their certainty in completing the current degree at this university with $58(90.6 \%)$ being very certain, $5(7.8 \%)$ somewhat certain, $1(1.6 \%)$ uncertain, and 1 $(1.6 \%)$ did not answer. Interestingly, only $71.4 \%$ of non-BME participants were very certain, while $19.6 \%$ were somewhat certain, and $6.3 \%$ were uncertain. When asked what made the BME participants attend a non-mandatory college event, $46.2 \%$ reported that friends would be there $(41.1 \%$ for non-BME), 35.4\% that it was at a convenient time and place (30.4\% non-BME), $27.7 \%$ because it was free or affordably priced (26.8\% non-BME), $35.4 \%$ as there was a perceived benefit to the participant's career (44.6\% non-BME), $23.1 \%$ because it looked like fun (31.3\% non-BME), and $3.1 \%$ reported other $(6.3 \%$ non-BME). As well, participants were also asked what made them decide to get involved in some aspect of campus life. BME participants reported that they got involved when they were passionate about the topic (61.5\%, compared to $64.3 \%$ for non-BME), when the involvement was perceived to look good on a CV $(33.9 \%, 7.1 \%$ non-BME), when they could see others contributing $(21.5 \%, 14.3 \%$ for non-BME), when someone the participant respected was leading $(9.2 \%, 18.8 \%$ non-BME), or other $(0.0 \%, 4.6 \%$ for non-BME). 
Table 6

Influencing factors for choosing and staying at university through percentage by racelethnicity

\begin{tabular}{|l|l|l|l|l|l|l|l|l|}
\hline $\begin{array}{l}\text { Student } \\
\text { Category }\end{array}$ & \multicolumn{3}{|c|}{ Asian } & \multicolumn{3}{c|}{ Black } & \multicolumn{3}{c|}{ BME } \\
\hline Factors & $\begin{array}{l}\text { Initial } \\
\text { Choice }\end{array}$ & $\begin{array}{l}\text { Choice/ } \\
\text { Stay }\end{array}$ & $\begin{array}{l}\text { Initial } \\
\text { Choice }\end{array}$ & $\begin{array}{l}\text { Choice/ } \\
\text { Stay }\end{array}$ & $\begin{array}{l}\text { Initial } \\
\text { Choice }\end{array}$ & $\begin{array}{l}\text { Choice/ } \\
\text { Stay }\end{array}$ & $\begin{array}{l}\text { Initial } \\
\text { Choice }\end{array}$ & $\begin{array}{l}\text { Choice/ } \\
\text { Stay }\end{array}$ \\
\hline Price & 26.7 & 16.7 & 4.2 & 12.5 & 13.8 & 15.4 & 4.7 & 8.0 \\
\hline Course & 76.7 & 66.7 & 50.0 & 58.3 & 61.5 & 60.0 & 58.0 & 66.1 \\
\hline Friends & 3.3 & 30.0 & 12.5 & 25.0 & 6.2 & 24.6 & 6.3 & 36.7 \\
\hline Family & 13.3 & 23.3 & 29.2 & 20.8 & 20.0 & 18.5 & 11.6 & 12.5 \\
\hline Location & 43.3 & 40.0 & 33.3 & 25.0 & 40.0 & 32.3 & 67.0 & 44.6 \\
\hline $\begin{array}{l}\text { Services and } \\
\text { Activities }\end{array}$ & 10.0 & 6.7 & 4.2 & 16.7 & 7.7 & 12.3 & 7.1 & 8.0 \\
\hline Other & 10.0 & 10.0 & 8.3 & 8.3 & 7.7 & 7.7 & 11.6 & 10.7 \\
\hline
\end{tabular}

For resilience, BME participants were first asked if they experienced challenges at the university, with 22 (33.9\%) reporting 'always', 38 (58.5\%) 'sometimes', $1(1.5 \%)$ 'never', and $4(6.2 \%)$ did not respond. Similarly, 32.1\% of non-BME participants reported 'always', 60.7\% 'sometimes', 4.5\% 'never', and $2.7 \%$ did not respond. Participants were also asked who they thought could help them overcome challenges at the university as well as who they actually spoke to when facing challenges, demonstrating high rates for friends and professors overall (see Table 7). Interestingly, Black participants were much less likely to actually contact professors when facing challenges.

Table 7

Potential and actual avenues for assistance when facing challenges by percentage

\begin{tabular}{|c|c|c|c|c|c|c|c|c|}
\hline \multirow{2}{*}{$\begin{array}{l}\text { Student } \\
\text { Category } \\
\text { Individuals to } \\
\text { Contact }\end{array}$} & \multicolumn{2}{|c|}{ Asian } & \multicolumn{2}{|c|}{ Black } & \multicolumn{2}{|c|}{ BME } & \multicolumn{2}{|c|}{ White } \\
\hline & $\begin{array}{l}\text { Potential } \\
\text { Avenues }\end{array}$ & $\begin{array}{l}\text { Actual } \\
\text { Avenues }\end{array}$ & $\begin{array}{l}\text { Potential } \\
\text { Avenues }\end{array}$ & $\begin{array}{l}\text { Actual } \\
\text { Avenues }\end{array}$ & $\begin{array}{l}\text { Potential } \\
\text { Avenues }\end{array}$ & $\begin{array}{l}\text { Actual } \\
\text { Avenues }\end{array}$ & $\begin{array}{l}\text { Potential } \\
\text { Avenues }\end{array}$ & $\begin{array}{l}\text { Actual } \\
\text { Avenues }\end{array}$ \\
\hline Friends & 53.3 & 66.7 & 45.8 & 45.8 & 47.7 & 55.4 & 55.4 & 65.2 \\
\hline Family & 30.0 & 30.0 & 37.5 & 37.5 & 27.7 & 30.8 & 36.6 & 38.4 \\
\hline Professors & 43.3 & 46.7 & 45.8 & 29.2 & 47.7 & 38.5 & 53.6 & 55.4 \\
\hline $\begin{array}{l}\text { Student } \\
\text { Support } \\
\text { Services/ } \\
\text { University } \\
\text { Departments }\end{array}$ & 16.7 & 13.3 & 37.5 & 25.0 & 27.7 & 24.6 & 33.9 & 17.9 \\
\hline
\end{tabular}

\section{Comparison between populations}

Race/ethnicity demographic variables (BME versus non-BME participants) were compared to ordinal categorical questions related to engagement and persistence through Mann-Whitney $U$ testing (see Table 8). Distributions of the engagement and persistence ratings for BME and non-BME participants were not similar, as assessed by visual inspection. Responses for the ordinal categorical questions were scored as follows: 'always' equated to 3, 'sometimes' as 2, and 'never' as a 1. Median scores were compared for each question independently, resulting in some questions which were statistically significant while others were not. Scores on making friends outside my classes for BME participants (mean rank $=100.78$ ) were statistically significantly higher than for non-BME participants (mean rank $=79.58), U=2679.5 z=-2.912, p=.004$. Scores on level of student engagement for BME participants (mean rank $=97.73$ ) were statistically significantly higher than for non-BME participants 
(mean rank $=79.85), U=2737.5, z=-2.467, p=.014$. For persistence, scores on certainty of degree completion at this university for BME participants (mean rank $=96.49$ ) were statistically significantly higher than for non-BME participants (mean rank $=81.43$ ), $U=2880.5, z=-2.733, p=.006$.

Table 8

Summary of Mann-Whitney $U$ results of questions for racelethnicity demographics

\begin{tabular}{|c|c|c|c|}
\hline Engagement Questions & $\boldsymbol{U}$ & $z$ & $p$ \\
\hline I feel valued by the faculty, staff and students at this university & 3159.5 & -0.789 & .430 \\
\hline It is easy to become part of campus life at this university & 3097.0 & -1.717 & .086 \\
\hline I feel like I belong on this university's campus & 3163.5 & -1.166 & .244 \\
\hline I feel social media helps me get connected & 3181.5 & -1.215 & .224 \\
\hline I feel a part of the broader community outside of this university & 3003.0 & -1.473 & .141 \\
\hline I make friends in my classes at this university & 3745.5 & 0.986 & .324 \\
\hline I make friends outside my classes at this university & 2679.5 & -2.912 & $.004 *$ \\
\hline My level of academic engagement is & 3040.0 & -1.448 & .148 \\
\hline I feel staff in Student Services know me and support me & 3202.5 & -0.599 & .549 \\
\hline My level of student life engagement is & 2737.5 & -2.467 & $.014^{*}$ \\
\hline \multicolumn{4}{|l|}{ Persistence Questions } \\
\hline I use campus resources when I need them & 3856.0 & 0.759 & .448 \\
\hline How certain am I that I will complete my degree at this university & 2880.5 & -2.733 & $.006 *$ \\
\hline I experience challenges at this university & 3162.5 & -0.621 & .534 \\
\hline
\end{tabular}

Note. $p<.05$

A Kruskal-Wallis $\mathrm{H}$ test was run to determine if there were differences in ordinal categorical questions related to engagement and persistence between four groups of participants (Asian, Black, Other and White participants; see Table 9). Values are mean ranks unless otherwise stated. Distributions of ratings were not similar for all groups, as assessed by visual inspection of a boxplot. Feeling a part of a broader community outside of the university scores were statistically significantly different between the race/ethnicity groups, $\chi^{2}(3)=8.898, p=.031$. Subsequently, pairwise comparisons were performed using Dunn's (1964) procedure with a Bonferroni correction for multiple comparisons. This post hoc analysis revealed statistically significant differences in scores between the Asian (106.73) and White (82.07) participants $(p=.049)$, but not between any other group combination. Making friends in my class scores were statistically significantly different between the race/ethnicity groups, $\chi^{2}(3)=9.286, p=.026$. Subsequently, pairwise comparisons were performed using Dunn's (1964) procedure with a Bonferroni correction for multiple comparisons. This post hoc analysis revealed statistically significant differences in scores between the Asian (98.87) and Black (67.69) participants $(p=.046)$, but not between any other group combination. Making friends outside my classes scores were statistically significantly different between the race/ethnicity groups, $\chi^{2}(3)=10.913, p=.012$. Subsequently, pairwise comparisons were performed using Dunn's (1964) procedure with a Bonferroni correction for multiple comparisons. This post hoc analysis revealed statistically significant differences in scores between the Asian (105.22) and White (78.58) participants $(p=.045)$, but not between any other group combination. Level of student life engagement scores were statistically significantly different between the race/ethnicity groups, $\chi^{2}(3)$ $=9.132, p=.028$. Subsequently, pairwise comparisons were performed using Dunn's (1964) procedure with a Bonferroni correction for multiple comparisons. This post hoc analysis revealed statistically significant differences in scores between the Other (119.73) and White (79.85) participants $(p=.037)$, but not between any other group combination. Certainty that I will complete my degree at this university scores were statistically significantly different between the race/ethnicity 
groups, $\chi^{2}(3)=8.231, p=.041$. Subsequently, pairwise comparisons were performed using Dunn's (1964) procedure with a Bonferroni correction for multiple comparisons but yielded no statistically significant differences.

\section{Table 9}

Summary of Kruskal-Wallis $H$ results of questions for racelethnicity demographics

\begin{tabular}{|l|l|l|l|}
\hline Engagement Questions & $\boldsymbol{\chi}^{\mathbf{2}}$ & $\boldsymbol{d} \boldsymbol{f}$ & $\boldsymbol{p}$ \\
\hline I feel valued by the faculty, staff and students at this university & 2.136 & 3 & .545 \\
\hline It is easy to become part of campus life at this university & 4.127 & 3 & .248 \\
\hline I feel like I belong on this university's campus & 2.502 & 3 & .475 \\
\hline I feel social media helps me get connected & 3.525 & 3 & .318 \\
\hline I feel a part of the broader community outside of this university & 8.898 & 3 & $.031^{*}$ \\
\hline I make friends in my classes at this university & 9.286 & 3 & $.026^{*}$ \\
\hline I make friends outside my classes at this university & 10.913 & 3 & $.012^{*}$ \\
\hline My level of academic engagement is & 2.366 & 3 & .500 \\
\hline I feel staff in Student Services know me and support me & 2.648 & 3 & .449 \\
\hline My level of student life engagement is & 9.132 & 3 & $.028^{*}$ \\
\hline Persistence Questions & & & .392 \\
\hline I use campus resources when I need them & 2.995 & 3 & $.041^{*}$ \\
\hline How certain am I that I will complete my degree at this university & 8.231 & 3 & .599 \\
\hline I experience challenges at this university & 1.873 & 3 & \\
\hline
\end{tabular}

Note. $p<.05$

\section{Discussion}

Overall, as reported in Table 1, it is interesting to note that there was a much higher percentage of females to males for BME categories (69.2\% BME females compared to 58.0\% non-BME females), most highly pronounced for Asian respondents (76.7\% Asian females). This is in line with previous reviews (Cotton et al., 2015). In addition, it would be easy to assume that more BME respondents from the metropolitan campus versus the suburban campus would participate, however, respondent rates were similar for both campuses in this study. Furthermore, factors and questions specifically around engagement and persistence demonstrated some interesting findings that may be beneficial to higher education faculty, staff and researchers alike.

\section{Engagement factors}

\section{Belonging}

Based on these results, only $52.3 \%$ of BME participants reported feeling valued at the university by faculty, staff and fellow students. Although this is comparable to White participants (50\%), it is important to note that upwards of $50 \%$ of all respondents did not feel valued by some or all of the university. As approximately $50 \%$ of all students (no matter race/ethnicity) did not feel valued by some or all of university faculty, staff and/or students, it is recommended that higher education institutions deploy strategies to assist students to feel valued within the university community through engaging and more inclusive curriculum, by intentionally reducing feelings of isolationism for BME students while respecting and promoting diversity within policies and day-to-day procedures (Tedam, 2014). Ross, et al. (2018) also suggested creating inclusive practices for faculty and staff to receive diversity and inclusion trainings, in an effort to provide an environment that is more conducive to BME students' academic and social engagement. It is also noteworthy to mention that Asian students appear to make more friends outside of the classroom settings and feel more connected to the broader community outside of the university than white participants, suggesting that they seek and/or find 
social support networks outside the university setting. Cotton et. al (2006) reported that BME students are less socially and academically engaged with their professors and peers, which might explain why BME students create or maintain more support networks outside of the university setting than within it. The BME participants in this study reported being very or somewhat active in student life activities more often than non-BME students (81.5\% compared to 61.6\%). While on campus, the connections formed through Student Life appear to be particularly important for minoritised students with regard to developing friendships and community outside of the classroom. Issues associated with belongingness and resulting levels of engagement can be positively impacted by participation in Student Life because the wider and deeper communication inherent within Student Life activities fosters opportunity for the development of multicultural understanding and interconnection (Shoderu et al., 2012).

\section{Student support services}

Almost $60 \%$ of BME students benefitted from more or higher impact interactions with student services staff when it came to experiences that encouraged feelings of being known and supported. Research suggests that high impact interactions include having discussions on race with staff and students, while being careful not to create a hostile environment or one in which BME students feel silenced, isolated, or invalidated (McDuff et al., 2018). With established rapport with student services staff, students may feel more comfortable seeking services when needed. It is important to note that representation of observed diversity within faculty and staff could play a significant role in whether or not BME students seek support on campus. Collins and Kritsonis (2006) argued that having a diverse faculty and staff can affect the rate at which BME students participate with university officials, because they are more likely to reach out to someone that represents their identity. It may also be important to recognise that preferred methods of receiving support appear to vary with ethnicity. Asian students in this study preferred to conduct communication with student services staff via email and were less keen on visiting the office and calling on the telephone, while Black students most often prefer to visit the student services office to communicate, followed by email and then the telephone. Comparatively, non-BME participants preferred to email, then to not communicate at all, followed by coming to the office.

\section{Academic engagement}

With regard to academic engagement, a higher percentage of BME students (56.9\%) reported that professors always helped them succeed in class compared to non-BME students (47.3\%). In addition, $86.2 \%$ of BME participants stated they were very or sometimes active and engaged in academic activities, which was slightly higher when compared to white participants (77.7\%). BME respondents most often prefer to communicate with professors via email, followed by coming to the professor's office during office hours and lastly approaching the professor before or after class. When considering what matters in the classroom, Asian participants were more comparable to White participants in their appreciation of faculty enthusiasm $(60.0 \%$ and $66.1 \%$ respectively), while Black participants were not as concerned with this attribute $(37.5 \%)$. Interestingly, non-BME students placed a higher importance on faculty expertise $(38.4 \%)$ and student rapport $(24.1 \%)$ than all categories of BME students $(27.7 \%$ and $10.4 \%$ respectively). In addition, although Asian and White students were comparable in their levels of confidence (approximately 44\% combined) in the classroom, only $16.7 \%$ of Black students reported feeling confident. It is noteworthy that fewer Asian students reported being hesitant in class $(10.0 \%)$, while $20 \%$ of both Black and White students reported being hesitant. Overall, all BME students were less likely to feel accepted $(33.8 \%)$ when compared to nonBME students $(41.1 \%)$. As well, the interest levels of groups of students during class were vastly different (36.7\% for Asian, 45.8\% for Black, and 55.4\% for White), suggesting a difference in response to learning environments. It is clear that many BME students felt that their professors wanted to help them succeed; however, the distinctive preferences and response patterns described suggest avenues for improving practices. Lastly, efforts to decrease Black student hesitation and increase 
confidence in the classroom is warranted. One recommendation for enhancing the academic engagement of all ethnic groups is by monitoring their academic achievement (Richardson, 2008). Active monitoring through student preferred communication channels establishes a mechanism to provide all students with regularised, equitable support from areas within the university that most effectively contribute to their success.

\section{Persistence factors}

\section{Decision making}

In terms of choosing to attend university, all groups of students reported that the availability of their course of interest and campus location were the two strongest motivators for their initial choice of the university and for their decision to remain. BME participants were more likely to report that they were certain of degree completion than non-BME participants (90.6\% and $71.4 \%$ respectively). As this was unexpected based on research on the persistence and retention of BME students, further research is needed to understand the cause of these results and determine what factors contribute to this population's confidence in degree completion. In addition, BME students reported they were most likely to attend a non-mandatory college event if friends would be there, if it was at a convenient time and place, and/or there was a perceived benefit to the participant's career. Therefore, events should be conveniently scheduled, encourage group attendance, and marketed in such a way as to highlight how attending events will relate to and improve aspects of the participant's career. In addition, campus life activities should promote networking, and offer programs and topics that students feel passionately about and/or which may be beneficial to include on a CV. Local campusbased research should be periodically conducted to determine areas of greatest passion for BME student populations.

\section{Resilience}

Finally, BME participants reported similar rates of challenges to non-BME participants $(33.8 \%$ and $32.1 \%$ respectively). All participant groups often turned to friends when faced with challenges. As well, professors were the second most commonly cited option for seeking assistance with all participant groups. However, there was a large discrepancy within the Black participants between perceiving professors could help (45.8\%) and actually seeking assistance from them $(29.2 \%)$ and perceiving student services staff could help (37.5\%) and actually seeking assistance from them (25.0\%). These results suggest that although Black (and White) students understand where to go to receive support services, they are hesitant to do so. More outreach and encouragement from professors and student services staff may ensure that all students utilise university avenues for assistance when challenges arise. In addition, Asian students perceived (16.7\%) and used (13.3\%) student support services at very low rates when facing challenges; therefore, it may be advisable to disseminate targeted information to Asian students on the benefits of accessing supportive services when needed or provide opportunities for mentoring.

\section{Future research}

As this study involved one university in the UK, it is recommended that further research be conducted to demonstrate reliability in the results. Similar studies should be facilitated in a diverse range of institutions both in the UK and across other regions of the globe to determine if these results are specific to this institution's population or to the region in which the institution is situated. In addition, a larger sample will allow for additional investigation between BME groups.

\section{Conclusion}

Higher Education in the UK has enjoyed a long, distinguished history but the progress on achieving equity for present day BME students is not keeping pace with present day demands (Bhopal, 2017). Research supports the notion that professional role models (faculty, student support staff, administrators) and a decolonised curriculum can and does positively impact inclusivity and increase 
BME student success. Yet, numerous contemporary scholars continue to identify a concerning attainment gap between BME students and their non-BME counterparts that should and can be addressed. This secondary investigation was conducted to examine aspects of surviving and thriving in UK universities from a minority lens. It sought to identify similarities and differences of the higher education experience related to retention and engagement viewed through a race and ethnicity lens. Numerous distinctions emerged that have relevance for closing the gap. Among the most compelling distinctions was a finding that BME students feel less valued at the university when compared to their White counterparts. Despite feeling less valued they were more likely to report that they were going to complete their degrees. It is important to investigate more deeply what factors contribute to feeling valued and how new, tangible measures of valuing can be activated. It is equally important to identify how and when high aspirations flounder in those who enter certain they will succeed yet fail to graduate. With their most important network of friends and support being outside the university, BME students may view themselves on the margins of the higher education experience and fail to find the support structures that they need. This may, in part, explain the hesitancy to speak up or speak out, as shared by many of this study's participants. Additional research should be conducted to further investigate this expressed hesitancy and to more fully determine the array of factors that contribute to the experience of 'obstacle' and provide actionable means to ameliorate. In addition, more interventions must be tested, and effectiveness proven in order to build evidence-based practices to create inclusion, equity and success for BME students within the structures of higher education. 


\section{References}

Anglia Ruskin University (2017). Student snapshot. (2017). Retrieved from: file:///E:/Spring\%202019\%20SAHE/ Study\%20Abroad\%20in\%20Higher\%20Ed/Articles/Anglia\%20Ruskin\%20Snapshot\%20of\%20Student\%20De mographics.pdf.

Bhopal, K. (2017). Addressing racial inequalities in higher education: Equity, inclusion and social justice. Ethnic and Racial Studies, 40(13), 2293-2299.

Boliver, V. (2016). Exploring ethnic inequalities in admission to Russell Group Universities. Sage Publications, 50(2), 247-266.

Collins, C.J. \& Kritsonis, W.A. (2006). National viewpoint: The importance of hiring a diverse faculty. National Journal for Publishing and Mentoring Doctoral Student Research, 3(1), 1-7.

Cotton, D.R.E. (2013). The gender and ethnicity attainment gap. Plymouth, UK: University of Plymouth.

Cotton, D. R. E., Joyner, M., George, R., \& Cotton, P. A. (2015). Understanding the gender and ethnicity attainment gap in UK Higher Education. Innovations in Education and Teaching International, 53:5.

DuVivier, R., Oswald, G. R., Steller, L., \& Bumhoffer, K. (2018) Surviving and thriving at a university in the United Kingdom. Journal of the Australian and New Zealand Student Services Association, 26(2), 87-98. https://doi.org.10.30688/janzssa.2018.09

Ethnicity Facts and Figures. (n.d.). Retrieved April 29, 2021 from https://www.ethnicity-facts-figures.service.gov.uk/

Harmon, N.S. (2009). A study of the experiences of black female student athletes at a predominantly white institution. University of Iowa.

Higher Education Statistics Agency. (N.d.). Table 14 - UK domiciled student enrolments by ethnicity and sex $2014 / 15$ to 2018/19. Retrieved from: https://www.hesa.ac.uk/data-and-analysis/students/table-14.

Index Mundi. (2019). United Kingdom Demographics Profile 2019. Retrieved from: https://www.indexmundi.com/ united_kingdom/demographics_profile.html\#: :text=white\%2087.2\%25\%2C\%20black\%2FAfrican,3.7\%25\% 20(2011\%20est.).

Institute of Race Relations. (2020). Retrieved from: https://www.irr.org.uk/.

Kim, Y. K., \& Lundberg, C. A. (2015). A structural model of the relationship between student-faculty interaction and cognitive skills development among college students. Research in Higher Education, 57(3), 288-309.

Landers, J. (1981). Quantification in history, topic 4: Hypothesis testing II-differing central tendency. Oxford: All Souls College.

Little, T. D. (Ed.) (2013). The Oxford handbook of quantitative methods, Vol. 2: Statistical Analysis. Oxford University Press.

McDuff, N., Tatam, J.C., Beacock, O. \& Ross, F.M. (2018). Closing the attainment gap for students from black and minority ethnic backgrounds through institutional change. Journal of Widening Participation and Life Long Learning, 20(1), 79-101.

Morales, E. E. (2008). The resilient mind: The psychology of academic resilience. The Educational Forum, 72(2), 152167.

Richardson, J. T. E. (2008). The attainment of ethnic minority Students in UK higher education. Studies in Higher Education, 33(1), 33-48.

Ross, F. M., Tatam, J. C., Hughes, A. L., Beacock, O. P., \& McDuff, N. (2018). “The great unspoken shame of UK higher education": Addressing inequalities of attainment. African Journal of Business Ethics, 12(1). https://doi.org/10.15249/12-1-172

Sanders, J., \& Rose-Adams, J. (2014). Black and minority ethnic student attainment: A survey of research and exploration of the importance of teacher and student expectations. Widening Participation and Lifelong Learning, 16(2), 527.

Shoderu, R., Kane, S., Husbands, D., \& Holly, D. (2012). Developing a sense of belonging: Findings from a three institution study with implications for BME students and staff engagement. Compass: The Journal of Learning and Teaching at the University of Greenwich, 5, 1-8.

Singh, G. (2009). Black and minority ethnic (BME) students' participation in higher education: Improving retention and success. Higher Education Academy: Evidence Net. 
Smith, S. (2017). Exploring the black and minority ethnic (BME) student attainment gap: What did it tell us? Actions to address home BME undergraduate students' degree attainment. Journal of Perspectives in Applied Academic Practice, 5(1). 48-57.

Stevenson, J. \& Whelan, P. (2013). Synthesis of the US literature relating to the retention, progression, completion, and attainment of black and minority ethnic (BME) students in higher education. Higher Education Academy: New York.

Tedam, P. (2014). Enhancing the practice learning experiences of BME students: Strategies for practice education. Journal of Practice Teaching \& Learning, 13(2/3), 130-145.

The National Archives. (2015). The National Archives - UK Government web archive. Retrieved February 20, 2020, from www.hefce.ac.uk website: http://www.hefce.ac.uk/media/HEFCE2014/Content/.

Universities and Colleges Admissions Service. (2020). UCAS terms explained. Retrieved from: https://www.ucas.com/ucas-terms-explained\#: :text=Second\%20class\%20honours\%20\%E2\%80\%93\%20most $\% 20 \mathrm{UK}$,division\%20(2\%3A2).

Walker, P. (2010). The commodification of British higher education: Trials and triumphs of massification in the metropolitan university. In L. Ang, J. Trushell, \& P. Walker, (Eds), Learning and teaching in a metropolis, (pp. 195-210). https://doi.org/10.1163/9789042027961_013

Worrall-Hill, C. (2014). Employability and students from BME backgrounds. Staffordshire, UK: Staffordshire University.

\section{The authors may be contacted via}

Gina.oswald@maine.edu

Please cite this paper as:

Oswald, G., DuVivier, R.,Wood, S., \& Freeman, T. (2021). Surviving and thriving at a UK university through a minority lens. Journal of the Australian and New Zealand Student Services Association, 29(1), 35-51. https:// doi.org.10.30688/janzssa.2021.1.05 